been found out that combined application of aerobic, power, speed, interval exercises, which are components of the experimental methodology, leads to a decrease in the body weight of women in the second period of mature age in conditions of independent classes.

Key words: Nordic walking, excess body weight, physical condition, experimental methodology.

УдК 378.046.4:004 (045)

\author{
Олександра Сологуб \\ Хмельницький обласний інститут \\ післядипломної педагогічної освіти \\ ORCID ID 0000-0003-4781-2973
}

DOI 10.24139/2312-5993/2019.05/256-268

\title{
ТЕХНОЛОГІЯ РОЗВИТКУ ІК-КОМПЕТЕНТНОСТІ МЕТОДИСТІВ РЕГІОНАЛЬНИХ СЛУЖБ У ПРОЦЕСІ ПІДВИЩЕННЯ КВАЛІФІКАЦІї
}

у статті розкрито структуру технології розвитку ІК-компетентності методистів міських (районних) методичних кабінетів (центрів), прачівників методичних служб об'єднаних територіальних громад у процесі підвищення кваліфрікації, виокремлено складники технології: концептуальний, цільовий, змістовий, процесуальний, оціночно-рефллексивний. Автор описує мету, обгрунтовує вибір підходів, принципів, змісту, форм, технічних засобів для реалізації технології, висвітлює психодізіологічні умови навчання дорослих слухачів, описує теоретичні та емпіричні методи дослідження, аналізує результати анкетування слухачів у ході експериментальної діяльності, планує подальшу роботу над дослідженням, спрямовану на коригування технології відповідно до результатів моніторингу.

Ключові слова: інформаційно-комунікаційна компетентність, методист регіональної служби, освітня технологія, технологія розвитку інформаційнокомунікаційної компетентності, дистанційні пролонговані тренінги.

Постановка проблеми. В умовах реалізації Концепції «Нова українська школа» важливо забезпечити процес розвитку інформаційно-комунікаційної компетентності методистів регіональних служб (методичних працівників міських (районних) методичних кабінетів (центрів), працівників методичних служб об'єднаних територіальних громад), які $\epsilon$ андрагогами, менеджерами професійного зростання педагогічних працівників. За результатами опитування, анкетування, спостереження констатуємо, що нерідко проблемою для методистів $\epsilon$ створення власних продуктів засобами інформаційно-комунікаційних технологій, організація співпраці та навчання у відкритих освітніх середовищах, фасилітація педагогів із питань використання цифрових технологій в освітньому процесі та ін.

3 метою створення умов для неперервного професійного та особистісного розвитку педагогічних працівників в умовах андрагогічного циклу на засадах випереджальності, адаптивності, відкритості освітнього процесу відповідно до сучасних вимог до організації навчання в закладах 
вищої освіти важливо на етапі реформування післядипломної педагогічної освіти здійснити оновлення освітніх технологій, а саме їх змісту, форм, методів тощо.

Аналіз актуальних досліджень. Проблеми модернізації системи підвищення кваліфікації в сучасних умовах, технології професійного розвитку педагогічних працівників відображені у працях вітчизняних науковців О. Бондарчук, М. Кириченка, Н. Клокар, В. Олійника, О. Отич, В. Сидоренко, М. Скрипник, Т.Сорочан та ін. Професійний та особистісний розвиток педагогічних працівників на засадах компетентнісного підходу досліджували Н. Бібік, О. Бондарчук, Ю. Завалевський, І. Зязюн, О. Карамушка, В. Кремень, Н. Ничкало, В. Олійник, М. Романенко, О.Савченко та ін. Питання стандартизації ІК-компетентності учасників освітнього процесу, підготовки керівних і педагогічних кадрів освіти до використання інформаційнокомунікаційних технологій розглянуто в роботах В. Бикова, Б. Гершунського, М. Гриньової, А. Єршова, Ю. Жука, М. Жалдака, Л. Забродської, О. Захар, А. Кочаряна, В. Лапінського, С. Литвинової, Н. Морзе, М. Носкової, О. Овчарука, В. Олійника, Ю. Рамського, О. Самойленка, О. Спіріна, Л. Чернікової та ін. Питанням організації освітнього процесу з використанням відкритого навчального середовища закладу освіти, упровадження технологій дистанційного навчання у процес підвищення кваліфікації присвячені праці В. Бикова, Н. Гущиної, К. Колос, С. Литвинової, Л. Ляхоцької, В. Олійника, О. Співаковського, О. Спіріна, С. Пойди та ін. Проте доводиться визнати, що питання технології розвитку ІК-компетентності методистів регіональних служб у процесі підвищення кваліфікації засобами дистанційних пролонгованих тренінгів у сучасних джерелах висвітлено, на нашу думку, недостатньо.

Мета статті полягає в обґрунтуванні технології розвитку IKкомпетентності методистів регіональних служб у процесі підвищення кваліфікації. Відповідно до поставленої мети окреслимо основні завдання: 1) описати основні складники технології розвитку ІК-компетентності методистів регіональних служб; 2) обґрунтувати вибір змісту, форм, технічних засобів для реалізації даної технології; 3) описати процес навчання слухачів на дистанційних пролонгованих тренінгах; 3) проаналізувати результати анкетування слухачів після завершення навчання за модулем «ІК-компетентність методиста. Базовий рівень» та окреслити шляхи подальшої роботи над дослідженням.

Методи дослідження. Теоретичні: аналізу, синтезу, моделювання для вивчення наукових джерел, нормативних документів 3 метою обґрунтування вибору змісту, форм, методів, технічного забезпечення 
технології розвитку ІК-компетентності методистів; емпіричні: формувальний експеримент, у межах якого проводилося діагностування, анкетування, тестування, опитування, оцінювання, самооцінювання, взаємооцінювання учасників експерименту, метод експертних оцінок, а також статистичні методи обробки даних, за допомогою яких визначались особливості організації освітнього процесу та відбувалося його коригування на кожному етапі реалізації даної технології.

Виклад основного матеріалу. Вітчизняні науковці трактують освітню технологію як «поетапне, покрокове досягнення спроектованого результату особистісного та професійного розвитку людини або групи осіб, які здобувають нові компетентності в процесі взаємодії суб'єктів освітнього процесу» (Олійник, 2017, с. 15). У своєму дослідженні ми також будемо керуватися визначенням педагогічної технології, яке відображено в документах ЮНЕСКО і витлумачується як системний метод створення, застосування й визначення всього процесу викладання і засвоєння знань $з$ урахуванням технічних і людських ресурсів та їх взаємодій, що ставить своїм завданням оптимізацію форм освіти.

Для визначення складників технології ми враховували: мету освітнього процесу, концептуальні засади (провідні ідеї, підходи, принципи, що сприятимуть розумінню технології), зміст, який визначається програмою розробленого нами курсу; форми та методи організації освітнього процесу, технічне забезпечення та людські ресурси; результати, які повинні досяпи учасники експерименту під час етапів з розвитку кожного з рівнів ІКкомпетентності та відповідну корекцію технології на кожному з етапів. Отже, до основних складників технології розвитку ІК-компетентності методистів регіональних служб відносимо: концептуальний, цільовий, змістовий, процесуальний, оціночно-рефлексивний.

Концептуальний складник. Педагогічна технологія розроблялася 3 опорою на андрагогічний, компетентнісний та аксіологічний підходи. Андрагогічний підхід спрямований на вдосконалення процесу підвищення кваліфікації з урахуванням психофізіологічних та соціальних особливостей дорослих слухачів, акцентування уваги на їх життєвому досвіді, освітніх та професійних потребах. Від оптимального поєднання викладачем-андрагогом навчальних методик у залежності від ситуації, побудови атмосфери довіри, взаєморозуміння та співпраці буде залежати, наскільки ефективно відбуватиметься процес підвищення фахового рівня освітян. Компетентнісний підхід змінює вектор освітніх пріоритетів, спрямованих на отримання знань, на процес розвитку компетентностей педагогічних 
працівників, що сприяє вирішенню професійних та життєвих проблем, їхньому професійному становленню, розвитку творчого потенціалу. Такий підхід спрямований на побудову кожним педагогом індивідуальної освітньої траєкторії, вибір видів та форм підвищення кваліфікації. Аксіологічний підхід характеризується спрямованістю освітнього процесу на формування толерантного ставлення між слухачами та викладачем, сприймання особистості слухача як найвищої цінності, опанування педагогами цінностей суспільства знань, сприйняття культур і традицій інших народів (Сологуб, 2018, с. 7).

Принципи, на яких базується освітній процес: випереджального розвитку, фасилітативності, самостійної і творчої активності, системності, неперервності й циклічності, гуманізації, опори на досвід того, хто навчається, варіативності, індивідуалізації, адаптивності, гнучкості та ін.

Важливою складовою концепту $\epsilon$ ефективне поєднання в процесі підвищення кваліфікації методистів формальної, неформальної та інформальної освіти. 3 цією метою в системі післядипломної педагогічної освіти запроваджуються гнучкі схеми організації освітнього процесу 3 залученням методичних працівників до різноманітних форм діяльності.

Цільовий складник. Постановка цілей та їх уточнення на кожному етапі у процесі роботи $є$ важливим складовим технології, який забезпечує досягнення результатів у визначені строки. Виходячи 3 соціального замовлення на розвиток інформаційно-комунікаційної компетентності особистості в умовах переходу до суспільства знань та враховуючи важливість підготовки педагогічних працівників до реалізації Концепції «Нова українська школа», ми визначили загальну мету технології як розвиток інформаційно-комунікаційної компетентності методистів регіональних служб у процесі підвищення кваліфікації. Відповідно, на кожному етапі ставилися цілі, виконання яких було підпорядковане загальній меті.

Змістовий складник. Під час підготовки змістової частини враховувалися визначені нами рівні (початковий, поглиблений, професійний та експертний), компоненти структури ІК-компетентності методиста (ціннісномотиваційний, когнітивний, операційно-діяльнісний та дослідницькорефлексивний), а також види діяльності методиста регіональної служби з питань використання IKT (розуміння ролі IKT та процесів інформатизації в освіті, використання IKT у професійній діяльності, сприяння розвитку IKкомпетентності педагогічних працівників, організація співпраці педагогічних працівників засобами IKT, оцінювання та моніторинг якості освіти засобами IKT, підвищення кваліфікації з питань використання IKT). 
Для реалізації поставленої мети нами розроблено програму курсу «ІКкомпетентність методиста». Модульна структура курсу дає можливість будувати індивідуальну програму розвитку для кожного слухача. До прикладу, програма модуля «ІК-компетентність методиста. Базовий рівень» розрахована на 18 годин і вивчається в межах пролонгованого дистанційного тренінгу. Тренінгова діяльність передбачає практичну спрямованість освітнього процесу. Під час навчання за базовим модулем відбувався процес розвитку в методистів технологічних навичок, що характеризує їх здатність розв'язувати прості завдання відповідно до видів своєї діяльності 3 використанням інформаційно-комунікаційних технологій: навички роботи 3 операційними системами, зокрема, вільно поширюваними, у тому числі встановленими на мобільних пристроях; інсталяція та деінсталяція програм на персональному комп'ютері та мобільному пристрої; робота з пакетами офісних програм для персональних комп'ютерів та онлайновими службами й додатками (документи, таблиці, презентації, форми); навички роботи 3 цифровими пристроями (фотоапарат, сканер), онлайновими програмами для опрацювання мультимедійних даних, а також установленими на персональному комп'ютері; уміння аналізувати, критично оцінювати інформацію в мережі Інтернет (захист персонального комп'ютера від негативного контенту, налаштування доступу до власної інформації в соціальних мережах; вжиття заходів, які запобігають крадіжці особистих даних у мережі Інтернет); педагогічний нетикет та ін.

Наступні модулі реалізуються за допомогою очно-дистанційної форми навчання. До курсу включені теми, завдання та практичні роботи, які відповідають професійним потребам методичних працівників, пов'язані з сучасними освітніми нормативно-правовими документами, сприяють орієнтації слухачів на саморозвиток та самореалізацію.

Процесуальний складник. Під час організації освітнього процесу ми враховували особливості навчання дорослих слухачів, які описують у своїх працях Р.Бабун, О.Бондарчук, С. Вершловский, Я.Катюк та ін. Ми погоджуємося з думкою О. Бондарчук, яка окреслює особливості керівників освітніх організацій як суб'єктів психологічної підготовки, і вважаємо, що вони повинні враховуватись у процесі підвищення кваліфікації методистів регіональних служб, які за своїми професійними обов'язками виконують функції менеджерів. Зокрема, необхідно враховувати їх попередній досвід, який може не відповідати тому, що їм буде запропоновано на етапі навчання; ознаки «емоційного вигорання», їх високий рівень тривожності та комплекс «загрози авторитету», систему психологічних захистів; систему смислів, 
цінностей, стереотипів, яка часто вирізняється певною інерційністю і якій викладачу важко протистояти. Тому, на думку науковця, велику увагу слід приділяти не стільки передачі знань даній категорії слухачів, скільки їх спрямуванню на професійний розвиток, вплив на слухачів на особистісному рівні, розвиток мотивації до самовдосконалення тощо (Бондарчук, 2014, c. 39). Я. Катюк, окреслюючи психолого-андрагогічні умови розвитку професійної компетентності працівників методичних служб у процесі підвищення кваліфікації, наголошує на активних методах навчання, переході від позиції «учитель-учень» до позиції «професіонал-професіонал», партнерські відносини, адже методист на рівні з викладачем може визначати мету, зміст підвищення кваліфікації, а його життєвий досвід може бути використаний викладачем як джерело знань (Катюк, 2015, с. 10).

Форми навчання, які ми обрали для реалізації технології: очна (лекція, семінар, конференція, ділова гра, тренінг, «круглий стіл», тематична дискусія, воркшоп, бар-камп та ін.); дистанційна (пролонговані дистанційні тренінги, відеолекції, групова робота в освітньому середовищі, самостійна робота в синхронному та асинхронному режимах).

Технології професійного розвитку: науково-методичний супровід (HMC), який «дозволяє подолати відірваність міжкурсового періоду та курсів підвищення кваліфікації, забезпечити неформальну неперервність післядипломної освіти педагогічних і керівних кадрів. Ця технологія передбачає залучення до вирішення педагогічних проблем широкого кола фахівців. Суб'єкти НМС не вирішують проблеми один одного, а здійснюють обмін думками, досвідом, інформацією, забезпечують всебічне обговорення проблеми та можливих підходів до їі вирішення» (Сорочан, 2016, с. 20), взаємодія у професійних мережах як технологія співпраці установ освіти з усіма потенційними партнерами для забезпечення ефективності освітнього процесу (Там само, 2016, с. 30).

Технічна підтримка курсу. Одним із світових трендів в освіті $\epsilon$ використання відкритого навчального середовища закладу освіти. В. Биков серед найважливіших інструментів системи відритої освіти, які суттєво впливають на ефективність навчання, виділяє технології мережного едистанційного навчання і зазначає: «У цих системах повинна збільшуватися евристична складова навчального процесу за рахунок застосування інтерактивного навчання та мультимедійних засобів навчального призначення, використання телекомунікаційних методів конструювання знань, набуття учнями досвіду електронного спілкування з усім світом» (Биков, 2010, с. 8). Дослідниця О. Локшина, аналізуючи Повідомлення Комісії 
Європейському Парламенту, Раді, Європейському економічному і соціальному комітету та Комітету регіонів «Відкриваючи освіту: інноваційне викладання і навчання для всіх засобами технологій і відкритих освітніх ресурсів», виділяє проблему з навчальним середовищем, яка викликана недостатнім рівнем володіння педагогічними працівниками цифровими навичками, які 6 сприяли використанню цифрових технологій в освітньому процесі, оцінюванню учнів засобами ІКТ (Локшина, 2017, с. 81). Саме тому звертаємо увагу на системи управління навчанням (Learning Management System або LMS) або CMS - Course Management System (система управління курсами), які набувають усе більшої популярності. Одним із достатньо нових сервісів для створення віртуальних навчальних середовищ є безкоштовний додаток Google Classroom, який оптимально відповідає потребам закладів освіти для створення віртуальних класних кімнат.

Для проведення пролонгованих дистанційних тренінгів була обрана платформа для проведення вебінарів Adobe Connect. Для груп слухачів були створені віртуальні класні кімнати в системі управління курсами Google Classroom. 3 кожної теми у класній кімнаті розміщувалися запис вебінару, текстова інструкція до виконання домашнього завдання, дидактичні матеріали (презентації, відеоінструкції, інтерактивні плакати, листи самооцінки, взаємооцінки, онлайнові ресурси та додатки для співпраці та ін.). Слухачі мали змогу обирати саме ті модулі, які вони хотіли б опанувати, це забезпечило можливість учасникам курсу будувати власну індивідуальну траєкторію навчання; відсутність установлених термінів здачі робіт дозволило працювати методистам в асинхронному режимі; домашню роботу слухачі здавали в середовище класу у вигляді файлів або посилань на створені ресурси, робота з кожної теми оцінювалася; вхідне, вихідне діагностування та формувальне оцінювання проводилося вбудованими у клас Google формами; для спілкування в мережі була створена група в соціальній мережі Facebook «Інформаційно-комунікаційні технології на допомогу методисту»; для забезпечення співпраці слухачів організовувалася спільна робота 3 інтерактивними онлайновими плакатами, Google картами та картами знань, групова робота в онлайнпрезентаціях, документах та таблицях google, проводилося взаємооцінювання; засоби формувального оцінювання дали змогу адаптуватися та вчасно реагувати на потреби слухачів. Зворотній зв'язок, можливість безпосередньої взаємодії між викладачем та слухачами під час проведення вебінарів досягався завдяки залученню учасників освітнього процесу до активної взаємодії в чаті та надання можливостей учасникам 
включати камери та мікрофони перед початком кожного вебінару та під час обговорення (рис. 1). Працівників методичних служб не обмежували термінами здачі домашнього завдання, що дозволило їм будувати власну траєкторію навчання.

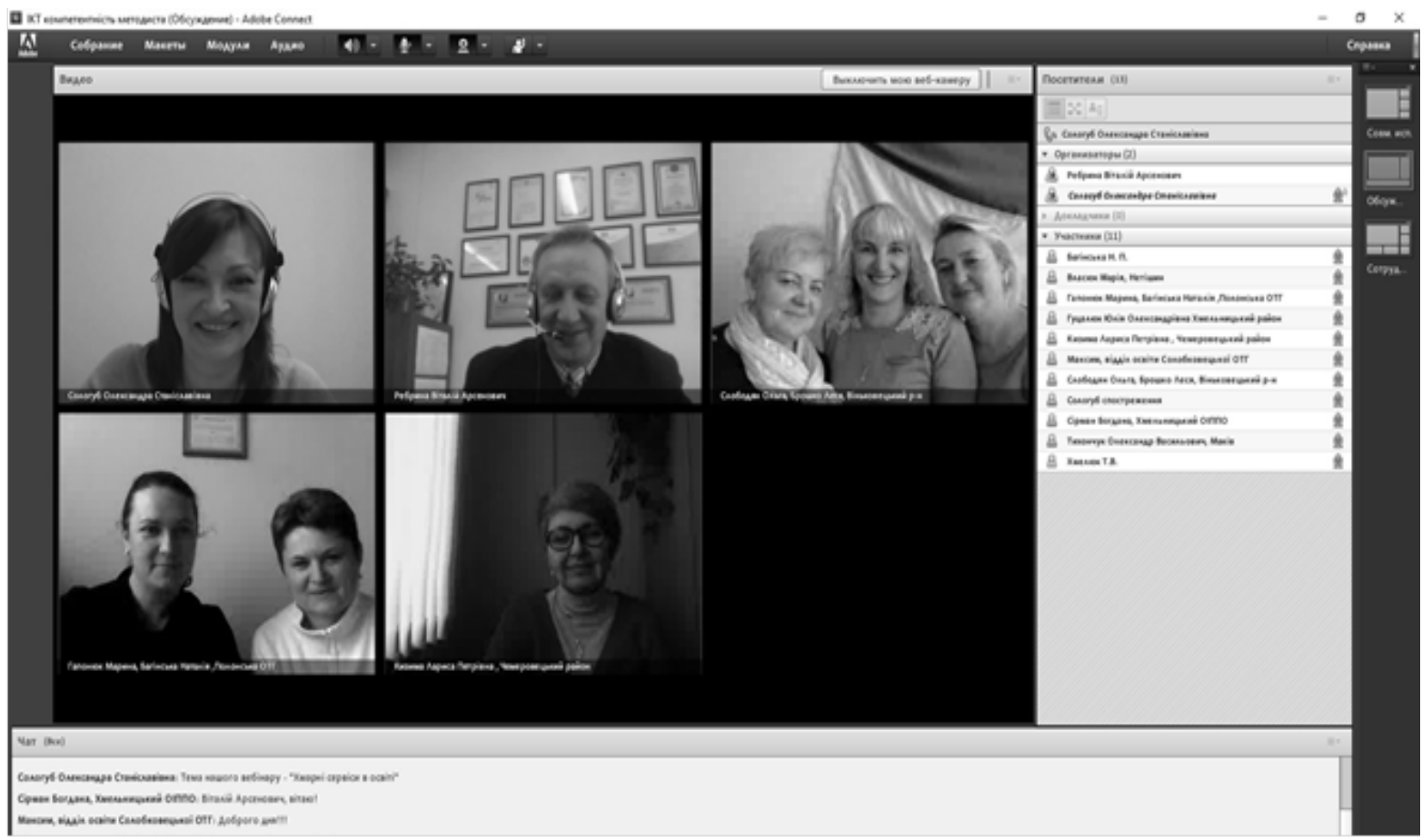

Рис.1. Налаштування камер та мікрофонів перед початком навчального вебінару в кімнаті платформи Adobe Connect

Серед можливостей додатку Google Classroom для організації класної роботи також виділимо створення необмеженої кількості учнів та класів, кожний із яких має свій код, за яким учні та вчителі можуть приєднатися; запрошення до викладання курсу більше одного викладача; інтеграція 3 Google диском, на якому і у викладачів, і в учнів автоматично створюється папка з матеріалами курсу; зручне управління навчальним контентом, об'єднання навчальних матеріалів за темами, установлення термінів виконання домашніх завдань; можливість архівації курсів після їх завершення; створення загальних звітів із оцінками слухачів та аналіз успішності кожного з них; систематизація виконаних, невиконаних завдань слухачами та тих, які очікують на перевірку (рис. 2); вбудований календар для кожного класу; наявність мобільного додатку; зв'язок та співпраця викладача й учнів через формування автоматизованих сповіщень на пошту Google та в середовищі класу; україномовний інтерфейс та ін.

Важливим етапом реалізації технології $€$ організація мережевої взаємодії між представниками формальної, неформальної та інформальної освіти. Така форма взаємодії дозволила нам визначити 


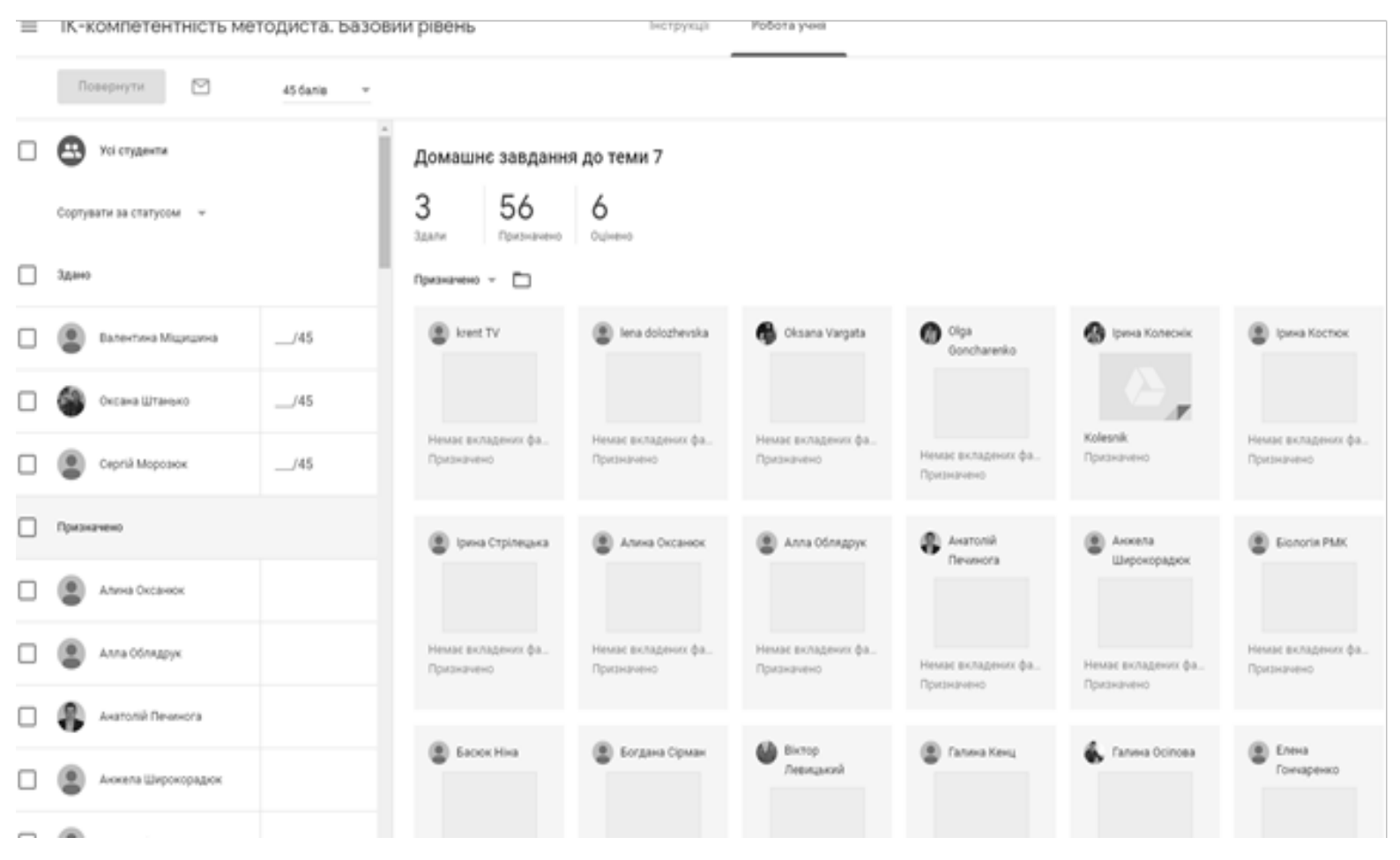

Рис.2. Інформація про виконання завдань слухачами одного 3 дистанційних курсів модуля «ІК-компетентність методиста. Базовий рівень» у віртуальній класній кімнаті Google Classroom

кадровий склад викладачів, які забезпечували процес підвищення кваліфікації, до нього увійшли: працівники кафедр Хмельницького обласного інституту післядипломної педагогічної освіти; тренери з числа вчителів, які висловили бажання поділитися досвідом з питань використання IKT та які $\epsilon$ сертифікованими тренерами від провідних компаній IT-галузі, зокрема, Microsoft та Google; викладачі кафедр вітчизняних закладів післядипломної освіти, з якими були укладені угоди про співпрацю; представники ITкомпаній. Для викладачів-тьюторів були проведені тренувальні навчання 3 питань проведення вебінарів на платформі Adobe Connect, створення навчальних відеолекцій, використання віртуального освітнього середовища для організації навчальної діяльності тощо.

Оціночно-рефлексивний складник включає оцінку робіт, які виконували слухачі та здавали у віртуальну кімнату Google Classroom, моніторинг рівня розвитку ІК-компетентності методичних працівників на кожному з етапів, а також опитування з метою оцінки умов, створених слухачам для організації освітнього процесу та здійснення коригування програм наступних модулів відповідно до потреб слухачів. Результати опитування після завершення навчання за першим модулем показали, що 
знання з тем після проходження базового курсу поглибились у 82 \% опитуваних, відповідь «Скоріше так, ніж ні» дали $15 \%$ опитаних, $3 \%$ відповіли «Незначною мірою» та жоден учасник не дав відповіді «Не поглибились». 100 \% слухачів вважають доцільним вибір дистанційної форми навчання на базовому тренінгу. 91 \% слухачів на запитання «Чи вважаєте Ви доцільним використання додатку Google Classroom для організації роботи на тренінгу?» відповіли «Так», 9 \% дали відповідь «Скоріше так, ніж ні», жоден із слухачів не дав негативної відповіді. $87 \%$ респондентів схвально оцінили поєднання записів вебінарів, відеоматеріалів, розміщених на каналі Youtube, та текстових інструкцій для виконання домашніх завдань, 13 \% опитаних відповіли, що достатньо було б лише записів вебінарів. На запитання «яку форму навчання Ви $б$ запропонували для тренінгів поглибленого та професійного рівнів?» 76 \% дали відповідь «Дистанційну», 22 \% - «Очнодистанційну», лише 2 \% обрали 6 очну форму навчання. 100 \% слухачів хотіли 6 опанувати на наступному тренінгу тему «Цифрове портфоліо методиста», $22 \%$ з них висловили бажання взяти участь у роботі творчої групи 3 обговорення питання контенту цифрового портфоліо. Лише 7 \% респондентів систематично проводять навчальні вебінари для педагогів, $37 \%$ уміють користуватися в кімнаті вебінару лише камерою та мікрофоном, 93 \% слухачів висловили бажання опанувати методику проведення вебінарів на наступних тренінгах 3 демонстрацією контенту 3 власного комп'ютера. $78 \%$ респондентів бажають пройти очне навчання по роботі з цифровими дошками, 9 \% з них бажають поділитися власним досвідом їх використання. На запитання «Чи будете Ви використовувати додаток Google Classroom y професійні діяльності?» 52 \% респондентів відповіли «так, для організації методичних об'єднань педагогічних працівників», $24 \%$ мають намір використовувати додаток для організації навчальної діяльності, лише 6,5 \% висловилися з приводу того, що в них немає потреби у використанні Google Classroom. На запитання «Чи вважаєте Ви доцільним не встановлювати терміни виконання завдань?» 75 \% відповіли «Так, можна будувати власну траєкторію навчання», 42 \% висловилися з приводу того, що були випадки, коли вони не встигали виконувати завдання до наступного вебінару, жоден не висловив побажання, щоб терміни здачі робіт були встановлені, адже навчання відбувалося без відриву від основного місця роботи.

Висновки та перспективи подальших досліджень. Підбиваючи підсумки, можемо констатувати, що врахування обґрунтованих нами складників технології сприятиме ефективному розвитку ІК-компетентності методистів регіональних служб. Подальша робота над дослідженням 
спрямовуватиметься на коригування програм наступних модулів відповідно до результатів моніторингу та побажань слухачів стосовно тем, які вони хотіли б опанувати.

\section{ЛITEPATУРA}

Communication from the Commission to the European Parliament, the Council, the European Economic and Social Committee and the Committee of the Regions "Opening up Education: Innovative teaching and learning for all through new Technologies and Open Educational Resources» \{SWD (2013) 341 final\}. Retrieved from: https://eurlex.europa.eu/legalcontent/EN/TXT/PDF/?uri=CELEX:52013DC0654\&from=EN.

Global Education Consortium. Global Network for Open Education. Retrieved from: http://www.oeconsortium.org.

Redecker, Ch., Punie, Y. (2017). European Framework for the Digital Competence of Educators: DigCompEdu. Publications Office of the European Union. Retrieved from: https://publications.europa.eu/en/publication-detail/-/publication/fcc33b68-d58111e7-a5b9-01aa75ed71a1/language-en.

Биков, В. Ю. (2010). Відкрите навчальне середовище та сучасні мережні інструменти систем відкритої освіти. Науковий часопис НПУ імені М. П. Драгоманова. Серія 2: Комп'ютерно-орієнтовані системи навчання, 9, 9-15 (Bykov, V. Yu. (2010). An open educational environment and modern network tools for open education systems. Scientific journal of the National Pedagogical University named after M. P. Dragomanov. Series 2: Computer-Oriented Learning Systems, 9, 9-15. Retrieved from: http://enpuir.npu.edu.ua/handle/123456789/703).

Биков, В. Ю., Овчарук, О.В. (2017). Очінювання інформачійно-комунікаційної компетентності учнів та педагогів в умовах євроінтеграчійних прочесів в освіті. Київ: Педагогічна думка (Bykov, V. Yu., Ovcharuk, O. V. (2017). Evaluation of information and communication competence of pupils and teachers in the conditions of European integration processes in education. Kyiv: Pedagogical Thought).

Бондарчук, О.І. (2014). Психологічна підготовка керівників освітніх організацій до діяльності в умовах змін: гуманістично-ціннісний підхід. Вісник Чернігівського національного педагогічного університету університет імені Т. Г. Шевченка, m. 1, 121, 38-43 (Bondarchuk, O. I. (2014). Humanistic-value approach in the psychological training of educational organization leaders to work in a changing environment. Bulletin of Taras Shevchenko Chernigiv National Pedagogical University. Vol. 1, 121, 38-43).

Зимняя, И. А. (2004). Ключевые компетентности как результативно-целевая основа компетентностного подхода в образовании. Авторская версия. Москва: Исследовательский центр проблем качества подготовки специалистов (Zimniaia, I. A. (2004). Key competences as the effective-target basis of competence approach in education. Author's version. Moscow: Research Center for Quality Problems in Training of Specialists).

Катюк, Я. Л. (2015). Психолого-андрагогічні умови розвитку професійної компетентності працівників методичних служб у процесі підвищення кваліфікації. Вісник післядипломної освіти, 12 (25), 80-90 (Katiuk, Ya.L. (2015). Psychologicalandragogical conditions of development of professional competence of workers of methodical services in the process of advanced training. Bulletin of Postgraduate Education, 12 (25), 80-90).

Локшина, О. (2018). Відкрита освіта в європейському просторі: стратегія розбудови. Педагогічні науки: теорія, історія, інноваційні технології, 2 (76), 75-86 
(Lokshyna, O. (2018). Open education in the European space: strategy of development. Pedagogical sciences: theory, history, innovative technologies, 2 (76), 75-86). Retrieved from: http://nbuv.gov.ua/UJRN/pednauk_2018_2_10.

Наказ Мон України "Про затвердження Концепції розвитку педагогічної освіти» (Order of the Ministry of Education and Science of Ukraine "On Approval of the Concept of Pedagogical Education Development"). (2018) Retrieved from: https://mon.gov.ua/storage/app/uploads/public/5b7/bb2/dcc/5b7bb2dcc424a80978 7929.pdf.

Національна стратегія розвитку освіти в Україні на період до 2021 року (National Strategy for the Development of Education in Ukraine until 2021) (2013). Retrieved from: www. http://zakon2.rada.gov.ua/laws/show/344/2013.

Олійник, В. В., Кириченко, М. О., Отич, О. М., Сорочан, Т. М., Бондарчук, О. І., Діденко, Н. Г., Скрипник, М.І.(2017). Проблеми і перспективи розвитку післядипломної педагогічної освіти в умовах розбудови нової української школи. Наукове забезпечення розвитку освіти в Україні: актуальні проблеми теорії і практики (до 25-річчя НАПН України), (сс. 382-391) (Oliinyk, V. V., Kyrychenko, M. O., Otych, O. M., Sorochan, T. M., Bondarchuk, O. I., Didenko, N. H., Serheieva, L. M., Klokar, N. I., Sydorenko, V. V., Skrypnyk, M. I. (2017). Problems and prospects of postgraduate pedagogical education development in conditions of development of a new Ukrainian school. Scientific support for the development of education in Ukraine: actual problems of theory and practice (up to the 25th anniversary of the National Academy of Sciences of Ukraine, (pp. 382-391)).

Семиченко, В.А. (2002). Психологічні проблеми навчання педагогічних працівників у системі післядипломної освіти. Розвиток педагогічної і психологічної наук в Україні 1992-2002: збірник наукових праць до 10-річчя АПН України. Ч. 2, 86-94 (Semychenko, V. A. (2002). Psychological problems of teaching staff in the system of postgraduate education. Development of pedagogical and psychological sciences in Ukraine in 1992-2002: collection of scientific works on the 10th anniversary of the Academy of Pedagogical Sciences of Ukraine. Part 2, 86-94).

Сологуб, О. С. (2018). Модель розвитку інформаційно-комунікаційної компетентності методистів регіональних служб у процесі підвищення кваліфікації. Електронне наукове фрахове видання "Адаптивне управління: теорія і практика» Серія "Педагогіка», 5 (9) (Solohub, O. S. (2018). Model of development of ICT competence of methodologists of regional services in the process of advanced training. International electronic edition "Adaptive management: theory and practice" series of "Pedagogy", 5 (9), 1-15). Retrieved from: https://amtp.org.ua/index.php/journal/article/view/30/22 .

Сорочан, Т. М., Скрипник, М. І. (2016). Технології професійного розвитку педагогів. Київ. Державний вищий навчальний заклад «Університет менеджменту освіти» (Sorochan, T. M., Skrypnyk, M.l. Methodological Advisor on Technologies of Professional Development of Teachers. Kyiv. State Higher Education Institution "University of Education Management").

\section{PEЗЮME}

Сологуб Александра. Технология развития ИК-компетентности методистов региональных служб в процессе повышения квалификации.

В статье раскрыта структура технологии развития ИК-компетентности методистов городских (районных) методических кабинетов (центров), работников 
методических служб объединенных территориальных общин в процессе повышения квалификации, выделены компоненты технологии: концептуальный, целевой, содержательный, процессуальный, оценочно-рефллексивный. Автор описывает цель, обосновывает выбор подходов, принципов, содержания, форм, технических средств для реализации технологии, освещает психофизиологические условия обучения взрослых слушателей, описывает теоретические и эмпирические методы исследования, анализирует результаты анкетирования слушателей в ходе экспериментальной деятельности, планирует дальнейшую работу над исследованием, направленную на корректировку технологии согласно результатам мониторинга.

Ключевые слова: информационно-коммуникационная компетентность, методист региональной службы, образовательная технология, технология развития информационно-коммуникационной компетентности, дистанционные пролонгированные тренинги.

\section{SUMMARY}

Solohub Oleksandra. Technology of development of ICT competence of methodologists of regional services in the process of advanced training.

In the context of reforming postgraduate pedagogical education, it is important to update the content, forms and methods for improving the skills of teaching staff. The article describes the structure of the technology of development of information and communication competence of methodologists of city (district) methodical offices (centers), workers of methodical services of the united territorial communities in the process of advanced training, the components of technology are distinguished: conceptual, purposeful, content, procedural, evaluative-reflexive. The author describes the purpose, justifies the choice of approaches, principles, content, forms, technical means for implementation of technology. The researcher analyzes the actual studies of modernization of the system of advanced training in modern conditions, the issue of organizing the educational process using the open educational environment of the education institution, introduction of distance learning technologies, describes the theoretical and empirical methods of research. Particular attention is paid to the psycho-physiological conditions of adult education. The conceptual component describes the approaches (andragogical, competency and axiological) and the principles on which the educational process is based (forward-looking development, facilitation, independent and creative activity, systemic, continuity and cyclicity, humanization, reliance on the experience of the learner, variability, individualization, adaptability, flexibility, etc.). The author draws attention to the importance of an effective combination of formal, informal and non-formal education in the process of qualification improvement of methodologists. The article also describes organization of the learning process at extended long distance trainings, analyzes technical features of the use of the Google Classroom Courses Management system, as well as the platforms for conducting Webinars for Adobe Connect. The author analyzes the results of the questionnaire of the students during the experimental activity: development of IC-competence of methodologists, assessment of conditions created for them during the educational process, methodologist's suggestions regarding the topics of the following module, plans further research aimed at adjusting the technology in accordance with the results of monitoring. The research has practical significance; this technology can be used when training adult listeners for distance learning.

Key words: information and communication competence, methodologist of the regional service, educational technology, technology of development of ICT competence, distance prolonged training. 